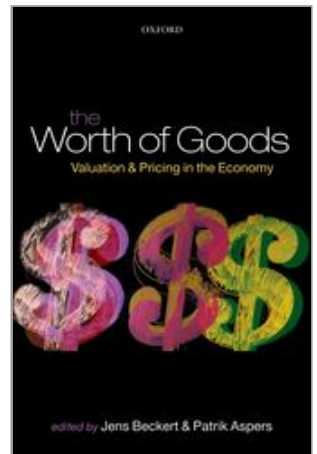

The Worth of Goods: Valuation and Pricing in the Economy

Jens Beckert and Patrik Aspers

Print publication date: 2011

Print ISBN-13: 9780199594641

Published to Oxford Scholarship Online: April 2015

DOI: 10.1093/acprof:osobl/9780199594641.001.0001

\title{
Value in Markets*
}

Patrik Aspers

Jens Beckert

DOI:10.1093/acprof:osobl/9780199594641.003.0001

\section{Abstract and Keywords}

This book deals with value and prices of goods in markets. More specifically, it examines how we place value on goods and why. It considers value in the broader sense, with particular reference to moral values and how they are formed as well as the relations between economic and non-economic values. It also analyses valuation in financial markets, focusing on credit rating agencies, stock exchange markets, and industrial production. A range of theoretical tools and case studies are presented to illustrate the nature of pricing and the creation of value in markets within social and cultural contexts and preconditions. By way of introduction, this chapter discusses markets, the economic and non-economic dimensions of value, the different perspectives on economic value that have developed in economics and sociology, and the valorisation of goods as part of the market process. It also describes how market actors evaluate goods, the social devices used to classify and categorise goods, the relationship between organisations and valuation, the dynamics of economic value, and the link between value and price.

Keywords: value, prices, goods, markets, economic value, valuation, financial markets, pricing, economics, sociology

The question "How much is it?" is often posed. We hear it when we buy something in the supermarket, but the businessman who wants to know the cost of having his bank help him to close a deal might pose the same question. "How much is it" often comes in the context of another question: "How much is it worth?" These are different questions, but they have been connected to each 
other since Aristotle. The centrality of these questions and the difficulties in understanding the underlying problems have not diminished since (Spates 1983).

This book focuses on value and prices in markets. Several recent events have brought the importance of this issue to the forefront. First came the collapse of Enron in 2001, where the fraudulent misrepresentation of profits and the value of the company's assets misled financial investors and finally culminated in the bankruptcy not only of Enron but also of Arthur Andersen, the accounting company approving Enron's financial statements. Then, in the financial crisis of 2008 , the erroneous assessment by rating agencies of the value of financial products like asset-backed securities and collaterized debt obligations triggered a bubble and the subsequent collapse of financial markets. Questions of value, however, are also important much more generally. For products to be sold in markets, customers must value them and assess their value in relation to other products. Firms must produce products and position them in the market where customers will consider them valuable. Financial investors must assess the value of assets through judgments of the opportunities and risks involved.

The problem of value is not restricted to contemporary capitalism. Assessments of value must be also made by exchange partners in the barter system that dominates exchange in traditional societies. The absence of money does not mean the absence of valuation. Questions of pricing and valuation appear in socialist economies as well, even when prices are not generated in and communicated through markets but are politically determined. The issue of value and valuation in production, consumption, and distribution appears whether we have a traditional or a modern economy, a socialist or a capitalistic system. However, the more the market has become the dominating mechanism steering the production and distribution of goods-substituting for (p.4) householding and redistribution as the dominant coordination mechanisms of traditional and state-run economies-the more significant the questions of valuation and pricing in markets have become.

The contributions to this volume focus on the value and prices of goods and on processes of valuation and pricing. By goods, we refer to consumption goods and capital goods as well as to financial assets. ${ }^{1}$ Despite the spotlight on markets, the scope of the chapters goes beyond markets because valuation and pricing cannot be understood as the outcome of markets viewed in isolation. Value is created by organizations and through networks; economic value is connected to social values and can be established independently from any intention to exchange a good on the market.

In this introduction, our aim is to contribute to the analysis of value and price. Economic sociologists have analyzed questions of value and price primarily in empirical case studies. Our ambition is to strengthen the tools for this kind of 
analysis by highlighting the multifaceted aspects involved in processes of valuation and locating the relevant features in relation to each other. We will start with markets, since discussing markets will lead us to identify the problems of uncertainty and order as the core problems underlying issues of valuation and pricing in markets. We will then discuss the notion of value in its economic and noneconomic dimensions and conceptualize how these facets interrelate. This is followed by a brief overview of the different perspectives on economic value that have developed in economics and sociology. In the subsequent section, we distinguish several dimensions of economic value and discuss the valorization of goods as part of the market process. We then discuss how market actors evaluate goods: the classification and categorization of goods that allows market actors to distinguish their value in relation to one another is one of the principal issues of the sociological treatment of economic value. Supported by concepts developed in economic sociology in recent years, we highlight the social devices allowing for the classification and categorization of goods. This analysis is followed by three sections which deal with additional topics crucial for a sociology of economic value: the relationship between organizations and valuation, the dynamics of economic value, and the link between value and price.

\section{Markets}

Markets are arenas of social interaction in which rights for goods and services are exchanged for money under conditions of competition (Aspers and (p.5) Beckert 2008; Fligstein 2001). Ideally, this exchange is voluntary and peaceful (Weber 1968: 17, 1922: 383), which follows from the assumption of respect for property rights. ${ }^{2}$

Markets are one form of coordination in the economy; others are hierarchies and networks. What distinguishes markets from these other forms of coordination is the role of competition. ${ }^{3} \mathrm{~A}$ market exists only if there is competition on at least one side of the market-demand or supply. Competition is a social relationship between two or more actors aiming for an end that cannot be shared (cf. François 2008). Market interaction is a form of indirect conflict (Simmel 1978). Suppliers or purchasers compete with each other based on offers that are mutually observed, evaluated, and eventually countered by new offers. For competition to emerge, actors must not only desire the goods offered and have the necessary purchasing power but they must be able to assess their qualities relative to each other and compare them in terms of their value. What makes a good valuable? How are they evaluated in markets and how are they priced?

These topics speak to the issue of uncertainty and order in markets. Order is the key question from which to understand the operation and the dynamics of markets (Aspers 2009, 2011; Beckert 2009b; Fligstein 2001). Order in a market presupposes that uncertainty in the market has been reduced (Beckert 1996; Jagd 2007). With regard to the issue of value and price, this uncertainty stems from the contingency of the value of products and from the difficulties in judging 
the qualities of the products offered in the market. The first issue refers to the valorization of products; the second issue to the assessment of the evaluation of goods in relation to one another (see Vatin 2009). Only if these issues can be resolved can the production and distribution of economic goods be coordinated through markets. Imagine yourself in a wine store or a gallery, or as a financial investor, and not knowing anything about wine, art, or equity. How could you make a sensible choice between the different offers? Would not the prices attached to the bottles, artworks, and stocks appear completely random?

\section{Value}

What makes a product valuable? Value has several interrelated dimensions. In social life, different forms of value are present simultaneously, such as moral (p. 6) value, aesthetic value, and economic value. Each form of value has a scale used for evaluating the things that value covers. An activity may be judged as more or less ethical, and an object may be more or less beautiful, more or less appropriate, or more or less expensive. These different scales of value exist concurrently, leading to different ways of evaluating social events, people, organizations, or objects. In this sense, Arjun Appadurai talks of different "regimes of value" (Appudarai 1986; cf. Moeran and Pedersen 2011). Being judged as a commodity is only one sort of "life" that a thing can have. Valuing something means measuring and comparing it according to a scale. Worth is a covering concept, encompassing all the different scales through which the value of an object or event can be assessed (Stark 2009).

Moral values such as solidarity, regard for human rights, or preservation of the environment are used to express something that is seen by a group or a society at large as right and good (cf. Graeber 2001: 1). Moral values can motivate action and form the basis for the assessment of goods. Moral values may also stand in opposition to one another (Boltanski and Thévenot 2006; Weber 1946), which is to say that they may be incommensurable.

Such clashes in the evaluation of an action, a person, an organization, or an object can also have their source in the use of the different scales applied for judging them. Objects can be assessed using aesthetic criteria, referring to their beauty, or using economic criteria, referring to the (monetary) equivalent an actor is willing to surrender in order to obtain property rights in the object. An action can be of high moral value but of little economic value, as when someone is caring for an animal that is ill. These valuations according to different scales may lead to conflicts over the assessment of the value of a good or an activity. To translate value from one scale to the other seems to be a categorical mistake, since there is no "exchange rate." This lack of a common scale is also why it is wrong to subsume the different forms of value constituting the worth of an actor, a product, or an organization under the notion of capital, as Bourdieu did, or to reduce these different forms of value to utility, as economists do. 
Nevertheless, these kinds of translations do take place. Observing how actors perform them and what kind of frictions emerge in the process is one of the main questions in sociological studies of valuation. In this volume, Marion Fourcade (Chapter 2) presents a highly informative case on the challenging relationship between economic evaluation and moral values. Fourcade studies the civil lawsuits that followed the devastating oil spills in Alaska. The question in these lawsuits was how to assess the destroyed value in animal and plant life: "goods" that were never intended to be evaluated economically or to be traded in a market. She shows that given the cultural framework of the United States, it was legitimate to translate the environmental damages into a measure of economic value. This translation was done by judging the economic value of the natural environment at Prince William Sound-the location of the oil spill. She thereby shows how economic theory is part of the technology used to evaluate the worth of the natural environment.

(p.7) Some of the most important work on the interface between economic value and moral valuation has been conducted in numerous studies by Viviana Zelizer. An example is her analysis of the early stages of the life insurance industry in the United States (Zelizer 1979), which shows that the emergence of this industry was initially blocked by religious beliefs that held life insurance to be morally offensive because the beneficiary would profit from the death of a loved one. Thus, moral values prohibited the economic value of the good from being considered.

Zelizer's historical analysis alludes to a much larger phenomenon: To be valuable in the market, goods must not only fulfill a need but must also find legitimation as being tradable in market terms. This means that valorization and normative evaluation are closely entangled. Which products find legitimacy is historically contingent. Following the taxonomy of Michael Walzer (Walzer 1983), it seems that at least in modern societies, the market exchange of objects related to the human body and to human life itself is considered particularly morally offensive, as is the market exchange of (political) decisions. This holds true for organ trafficking as well as for human trafficking, enslavement, and the purchasing of votes (Healy 2006; Steiner 2010). If potential customers consider the market exchange of a certain good as illegitimate and do not demand the product, no market will emerge. This happened with life insurance policies when they were first introduced in the United States. If the moral offensiveness of the exchange leads markets for this product to be prohibited, but demand exists for it nonetheless, then illegal markets will emerge. Examples of this are the alcohol market in the United States during prohibition (Welskopp 2010), as well as the illegal markets for drugs, counterfeit consumer products, and human organs (Scheper-Hughes 2004). Another response to a situation in which economic evaluation seems illegitimate is to obscure the economic dimension of the 
exchange (Bourdieu 1996). The art market provides an example of this case (Velthuis 2005).

That economic criteria must be judged as a legitimate basis of evaluation of the product to be exchanged shows one important connection between markets and morality. Moral values can block markets. Moral values, however, can also contribute to the value of products. ${ }^{4}$ Goods produced organically or with a social conscience are in high demand in many consumer markets today. "Fair trade" is a small but rapidly growing market segment (Zick-Varul 2009). The rise in demand holds true for groceries, sport shoes, flowers, wood furniture, or other products produced under morally defined criteria. Consequently, demand must be understood in relation to values of good health, care for workers, animals, and the environment at large (see also the chapter by (p.8) Peter Gourevitch in this volume). In financial markets, we find small but rapidly growing segments of Islamic investment and ethical investment, both of which combine moral values with economic value in assessing the worth of an asset. In other cases, the connection of a product to moral values constitutes the very thing that makes it possible for a market to develop, for example the emergence of a tourist market for whale watching (Lawrence and Phillips 2004). The "product" in this market consists of a boat ride off the coast that provides tourists the opportunity to observe whales swimming in the ocean. This product only became valuable once whales had become symbolically associated with values of freedom and unspoiled nature. Hence, what is valued in markets correlates with what is valued outside of markets. Moral values are distinct from economic values; they are, however, economically relevant (Weber 1978).

\section{Economic Value in Social Science}

Economic value in markets refers to the assessment of goods or services in terms of how much money an actor is willing to surrender to obtain property rights to the good in question. Money is used as the common denominator to assess the value of goods: it makes qualitatively different objects commensurate on a common scale of prices. Money is the means of account for economic value, but it is also a means of storing economic value. ${ }^{5}$ The discussion of money in sociology (Carruthers and Ariovich 2010; Dodd 1994; Ingham 2004; Simmel 1978) shows how money affects social relations. Money thus cannot be seen as a neutral measuring rod if we want to understand how economic values emerge.

The question of where the economic value of products derives from has a long history in economic thought that is closely related to fundamental transformations of the economic order. Aristotelian ideas of use value and exchange value formed an important foundation for thinking about the matter of value in relation to markets. The physiocrats, writing before the industrial revolution and at a time when political power was rooted in landed property, held the idea that only agriculture could yield a surplus-a produit net. According to the physiocrats, the manufacturing process used the same amount 
of value as input as what it produced as output, and hence created no added value. Classical political economy, most notably in the works of Adam Smith and David Ricardo, prospering in the early stages of the industrial and the bourgeois revolutions, challenged this position. Its labor theory of (p.9) value-which has a forerunner in Aristotle-saw the value of goods as stemming from the transformation of natural assets through labor. The value of a product could be measured as the work hours needed to produce it. Karl Marx followed the assumption of classical political economy that value is produced by the laborers in the labor process.

In Marx's theory, the market has at best an indirect role in the determination of value, because value is created in production. ${ }^{6}$ This theory misses the essential point that economic value expresses a relationship between the qualities of products offered in the market and the wants of customers and sellers. The intuition that goods have no intrinsic value has paved the way for modern economics. Most notable is the idea of marginal utility, developed at about the same time by William Jevons, Carl Menger, and Léon Walras, who saw value as utility, or more specifically the utility of the last added item. Instead of continuing to differentiate between market price and value, marginal utility theory took the sweeping step of giving up on any objective measure for assessing economic value-be it land, labor, or anything else-and anchoring value exclusively in the sphere of market exchange. This also means that valorization and evaluation (Vatin 2009) cannot be clearly distinguished anymore. $^{7}$

Neoclassical economics advocated a radical subjectivation of value through the introduction of the notion of marginal utility. During the 1930s, Lionel Robbins defined economics as "the science which studies human behavior as a relationship between ends and scarce means which have alternative uses" (Robbins 1935: 16). This formal definition is narrow, and it excludes noneconomic values; these become relevant only as inputs of what people desire. ${ }^{8}$ The subjective notion of economic value has also been advocated by sociologists. For Georg Simmel, looking at the demand side of markets, value follows from the distance between an actor and an object he desires: "The object...which is characterized by its separation from the subject, who at the same time establishes it and seeks to overcome it by his desire, is for us a value" (Simmel 1978: 66).

While we agree with marginal utility theory that economic value is an effect of the wants of potential purchasers-however manipulated by the producer sidewe also maintain that the theory of exchange offered by marginal utility (p.10) theory does not suffice to develop a theory of economic value. This is most obvious in the failure of neoclassical economics to develop a theory of preference formation. Marginal utility theory treats preferences as exogenous and does not take interaction in markets into account as a factor that may form 
and re-form preferences. The assumption made is that market participants each enter the market with fixed preferences for a bundle of goods and are restricted in their purchases through the respective budgets available to them.

Neoclassical theory is interested in the questions of how demand changes against changes of relative prices and how prices change with variations in the demand for products. Hence it offers a theory of market exchange. What remains necessarily opaque in such a theory is the explanation of actors' preferences themselves. "De gustibus non est disputandum" is the famous formula employed by George Stigler and Gary Becker (Stigler and Becker 1977) to bar questions of preference formation from the theory, but this has led to a situation in economics where "no one knows why people want goods" (Douglas and Isherwood 1979: 15).

Exogenizing preferences is possible only to the extent that neoclassical theory limits itself to explaining how market equilibria emerge based on existing preferences. However, such a theory remains incomplete because it remains silent on the origins of preferences. To start from a situation in which "all actors have a perfectly defined utility function is to suppose that the 'market question' is already partially solved" (Jagd 2007: 84). And to the extent that market equilibria are affected by endogenously changing preferences, a theory that exogenizes preferences cannot reach its goal of explaining the observable equilibria. It is this systematic point at which sociological approaches to the question of valuation in the economy set in.

To be sure, the limitations of neoclassical economics do not apply to all economists. Some strands of economics have taken up issues of endogenous changes in preferences and of explaining the origins of preferences. The bandwagon and snob effects refer to changes in demand due to the consumption patterns of others (Leibenstein 1950), violating the assumption that preferences are independent from the preferences of others. For some products, demand increases with price, meaning that price is itself valued as a cultural signal in markets and influences demand (the Veblen effect). While recent branches of economics are beginning to open the black box of preferences to scientific exploration, ${ }^{9}$ they do so primarily on psychological grounds. (p.11) The scope of psychological assessments is limited if desires for objects are seen as natural rather than cultural and social. It is the conviction expressed throughout this volume that investigations of the valuation of goods and changes of these valuations need to focus on the meanings that goods obtain for actors and on the social and institutional structure of markets.

\section{Dimensions of Economic Value}

A theory of economic value must explain both how economic value is socially constituted and how economic value is the result of markets. To examine value assessments in markets, it is helpful to distinguish analytically between the questions of what it means to say that a good provides value for an actor and the 
question of how actors determine the value of a good. The first question refers to the dimensions in which a product or an asset can be valuable, the second to their evaluation.

Value is not intrinsic to the materiality of an object but rather is inseparably connected to the concept of meaning (Richins 1994: 504). Even products whose value consists of the satisfaction of innate needs must be "understood" by the user as fulfilling this need and legitimated as a means for the satisfaction of the need. Despite this general dependence on meaning, it is possible to distinguish different forms in which goods can become economically valuable to the purchaser. Three such distinctions are especially illuminating to understand the sources of value:

1. The distinction between use value and investment value. Use value refers to what is gained from the qualities of a good through its use. Buying a soft drink at the soccer game, an axe to cut wood for heating, or a car for transportation are all purchasing decisions in which the value of the objects is based on the satisfaction stemming from their use.

Investment value of a good, in contrast, derives from the expectation of a monetary gain to be realized. Investments in financial markets are an example of this. Financial assets may gain in value but also provide a stream of revenue through interests or dividends. In addition, liquid financial assets, including money, may provide implicit revenue in the form of what Keynes called the liquidity premium. Purchases of capital goods and the contracting of workers are based on the expectation of deriving a profit. To buy a car and use it as a taxi to make a profit is based on its investment value; to buy the car for leisurely trips on the weekend is based on its use value.

(p.12) The distinction between use value and investment value is analytical, because in many cases both dimensions overlap. Buying a house is based on its use value in providing shelter, but it is also an investment if the buyer speculates that the house will go up in value. Purchases of artwork are characterized by a similar mixture of use value and investment value. Conversely, objects that seem to have their primary value in their investment dimension are also not entirely separated from use value. Setting up a production site can provide an intrinsic satisfaction and confer social status on the owner. Investment value and use value may also be connected through a prolonged means-ends chain. The profits from the investment might-though not necessarily (Deutschmann 1999)-be intended for consumption purposes. A person who buys stocks may do it because he wants to use the expected profit to buy a sports car. The distinction between use and investment hence has nothing to do with the inherent qualities of the items; it is purely a matter of the economic flow of meaning in which it is embedded. 
2. The distinction between individualistic value and relational value. Individualistic value refers to the satisfaction of a buyer's desire regardless of any social interaction effects associated with the purchase. A person who buys a cake for an afternoon snack or a bouquet of flowers for their home may do so independently of any orientation to third parties. "Individualistic value" does not mean that the desire for cake or for a bouquet of flowers would not be socially shaped. The purchase, however, can be made regardless of the reactions of third parties to it. Conversely, buying the same cake for a social gathering or giving the bouquet of flowers as a gift are examples of the relational sources of value. Relational value is based on what other people think, or are perceived to think, about the purchaser of the good based on what has been bought. The teenage boy who buys a pair of expensive sneakers to avoid being bullied by his peers is as relational as the father who replaces his car so as not to fall behind in status among his colleagues. Again, this is an analytical distinction because the very same good can have individualistic and relational value at the same time, depending on the flow of meaning in the exchange process. In this volume, Michael Hutter (Chapter 9) testifies to the importance of individualistic value in his analysis of how the "amazement" and "surprises" experienced by the spectators in a theatre, opera, or any other cultural event create value. Conversely, Pierre Bourdieu (Bourdieu 1984) has investigated the relational dimension of goods by showing how different consumption patterns express differences in cultural capital and how people employ this cultural capital to position themselves in the social field. Different tastes in music or different styles of home furniture are tools that actors use to distinguish their lifestyles and to signal their place in the social space.

(p.13) 3. The distinction between functional and symbolic value. A good that is bought because of its function allows its owner to use it to alter a state of the world based on the physical effect of the good. Symbolic value, by contrast, refers to the meaning a good has for its owner and in the owner's social environment that extends beyond the good's physical effects. Symbolic value is also only analytically independent from functional value, because often both come together in the same object. The house not only provides shelter (its physical effect) but is also a home. It can be a status symbol, signaling the social position of the owner to his social surroundings. In general terms, the ownership of products is part of the construction of the identity of the consumer (McCracken 1988) or the firm (Podolny 1993; Uzzi and Lancaster 2004) and therefore always has symbolic dimensions.

Symbolic value has been central in sociological research. It is based on intersubjectively shared meanings. What an object symbolically stands for is established in the community and emerges in social practices. ${ }^{10}$ Jens 
Beckert (Chapter 5) discusses in this volume a specific form of symbolic value he refers to as "imaginative value." Some goods not only position their owners in the social space through their symbolic signification but are also symbolic representations of espoused ideals and values that can be imaginatively appropriated through the purchase of goods. Goods can serve as bridges to the transcendental. There are examples of this potential for transcendence in consumer goods as well as in financial investments and entrepreneurial activity.

Seen on the aggregated level, the symbolic meaning of goods is an important element of the reproduction of class structures. Thorstein Veblen's classic description of conspicuous consumption (Veblen 1953) still provides the most graphic representation of how goods are utilized to symbolically demarcate social positions. Subsequent research has demonstrated with much broader scope how purchasing decisions in general are used to communicate identification with specific social identities (Warde 1994).

Though value based on symbolic meanings of goods is as old as the production of wealth beyond mere physical survival, it plays an especially important role for economic growth in affluent contemporary societies in which basic needs have already been satisfied (see also the chapter by Hutter in this volume). Now that land and labor have been identified as dominant sources of value in earlier times, the question arises: Are symbolic meanings to be understood as the leading sources of value today?

(p.14) Value through Evaluation Identifying the different dimensions in which goods and services become valuable to the buyer does not yet address the question of how market participants arrive at their judgment of the value (desirability) of the good offered in the market. This question refers to the evaluation of goods. How do financial actors make choices between different assets, given the uncertainty they confront? How do consumers choose between hundreds of models offered in the car market? These questions might seem trivial at the outset, because experience tells us that, at least in consumer markets, we have seemingly spontaneous ways to assess the goods we confront in most situations. And indeed, many purchasing decisions are made routinely.

A more detailed look at the question of how value is determined, however, reveals a highly complex world of social mechanisms standing behind the seemingly unproblematic task of producers and consumers to make value judgments in the market. This issue is directly connected to the problem of uncertainty in markets and forms one of the core issues in the sociological investigation of economic value. Only if buyers are capable of "forming clear subjective values for goods in the market" (Koçak 2003: 8), meaning that they are in a position to distinguish between the values of goods, and if sellers can 
reliably demonstrate the value of their goods, will uncertainty be reduced and a disposition to buy arise (Koçak 2003: 5-6). Market coordination presupposes a shared understanding of the qualities of goods (Eymard-Duvernay 2002: 268). This connection of the problem of the order of markets with the issue of valuation manifests itself among purchasers as well as among producers. On the demand side, customers need to compare goods offered in the market and make judgments on the desirability of these goods in relation to other offers. On the supply side, producers must demonstrate the value of their offers in relation to other products offered in the market.

The symbolic qualities of products that constitute their economic value must be constructed. This is done through practices of qualification of products. In the financial markets, for instance, the existence of a representation of the future is not given a priori but is the result of market exchange itself (Beunza and Garud 2005; Jagd 2007). In consumer markets, signification systems are produced and reproduced through the practices of consumers, producers, and market intermediaries, and the interactions between them (Callon et al. 2002). The process-driven character of the valuation of goods in social practices counters the idea of exogeneity of preferences. An empirical investigation of such practices is provided in this volume by Christopher Yenkey (Chapter 11), who analyzes the birth of the stock market in Kenya. Until recently, shareholding was unknown to private investors in Kenya. With the privatization of formerly stateowned firms and a nascent field of initial public offerings, a new market became possible. Potential buyers of shares, however, had to be "attached" to this form of investment by becoming (p.15) convinced of the worth of shareholding before the market could develop. Yenkey shows how advertising campaigns led by state agencies were actually creating the value of the shares offered.

The role of producers is crucial in these processes. Product differentiation as a form of value creation among producers is mentioned by Alfred Marshall (1920: 300-2), but today it is especially associated with the work of Edward Chamberlin (1948). Product differentiation is also the starting point in Harrison White's theory of producer markets (White 1981, 2008). White argues that firms competing in producer markets establish market niches that correspond with their identities. On the one hand, producers share the identity of being producers in the same market; on the other hand, they have different identities because they produce heterogeneous products. Product differentiation and the perceived value of the products is the outcome of the reciprocal orientation of producers toward each other.

Producers and market intermediaries are actively pursuing the creation of the value of goods. According to Alfred Marshall, value emerges from wants, which in turn result from activities. Wants make up the demand side and activities represent the supply side (1961). To understand the evaluation of products by customers, one needs to look at how producers and market intermediaries judge 
products in markets. There is a plethora of strategies and techniques that producers and sellers may employ to create, establish, and attribute value to their products. One field in which such strategies can be observed especially well is the fashion industry (Aspers 2010), which perhaps more than any other industry is characterized by symbolic rather than functional value production. By creating identities for firms and products through the means of narratives, visual communication, and connections between customers, and by using advertising, producers create niches and rank orders among themselves, as a result of interaction in the market.

This weight of the producer side in the valorization of products can also be observed in business-to-business markets, for example in the purchasing decisions of companies and in financial investments. Brian Uzzi and Ryon Lancaster provide an example of this in their findings that price differences between corporate law firms are based on the different symbolic value they offer to their clients (Uzzi and Lancaster 2004). Customers derive "the 'emotional part' of a purchase" from their perception of a law firm as having high status (Uzzi and Lancaster 2004: 328). The influence of status on the price charged by the law firm is based on two mechanisms: the desire of the client firm to improve its own image by associating itself with a high-status law firm, and a logic of appropriateness: Hiring a high-status law firm protects the internal counsel responsible for the decision "from potential criticism and raises their worth in the eyes of others" (Uzzi and Lancaster 2004: 328). This symbolic value allows higher prices to be charged for the legal service.

What does the situation look like when we turn to the consumers? Not only are market actors confronted with a large heterogeneity of different types of goods among which they must allocate their budget, but these actors often have (p. 16) a myriad of products to choose from within each category. The main issue in the evaluation of goods is their classification-an issue whose investigation has a long history in sociology (Durkheim and Mauss 1963; Espeland and Stevens 1998; Lounsbury and Rao 2004; Schneiberg and Berk 2010; Zuckerman 1999). To classify objects means to put them into categories that establish distinctions and at the same time make the objects commensurable. The classification of commodities leads not only to differentiation between different markets but also to recognized distinctions between the objects traded in one market, thereby reducing complexity (Musselin and Paradeise 2002: 257). For instance, fourwheeled motor vehicles form a market category that is distinct from motorcycles. Within that market, trucks are distinguished from passenger vehicles. Within the market for passenger vehicles, family cars are distinguished from sports cars and from SUVs. Within the category of family cars, there are models from Toyota, Volkswagen, Renault, and other producers. 
Producers may try to impose categories, but consumers may accept or reject these attempts. The classifications of products according to perceived differences contribute to the ordering of the complex and almost infinite world of commodities. However, the classification of products as such does not yet resolve the problem of valuation. Viewed from the demand side, making a decision in favor of an SUV depends on a value judgment: given the purpose for which the car is intended, the SUV is a better or more appropriate choice than a sports car. Similar choices must be made when deciding on a Volkswagen instead of a Toyota. How do potential purchasers of commodities arrive at such value judgments? How do they decide on a lawyer without having full information on what that lawyer's services are worth (Karpik 2010)? How do financial analysts assess the value of a stock or a bond despite the uncertainty involved (Beunza and Garud 2006; Zuckerman 1999)? How do consumers arrive at a choice between products that are interchangeable but not identical? These questions can only be answered based on judgment of the goods' qualities, that is, the qualification of a good-a process that requires the good's "individualization" (Callon 2002: 267).

Note that the problem of judging qualities is not limited to the "market for lemons problem" described by information economics (Akerlof 1970). The problem is not one of asymmetrically distributed information but of establishing what qualifies as quality. Much research in economic sociology has focused on the processes of qualification of goods as an indispensable part of the constitution of market value. Concepts like framing (Beunza and Garud 2005; Biggart and Beamish 2003; Fiss and Kennedy 2009), status (Aspers 2009; Podolny 2005), networks (Granovetter 1995; Uzzi and Lancaster 2004; White 1981), qualification (Callon 1998; Callon et al. 2002), market devices (Callon et al. 2007), judgment devices (Karpik 2010), and circuits of commerce (Zelizer 2004) have been applied to investigate how market actors arrive at judgments on the qualities of products offered in the market.

In addition to approaches in economic sociology, the economics of conventions (Eymard-Duvernay 1989; Favereau and Lazega 2002; Orléan 2004; Salais (p.17) and Thévenot 1986) has addressed this question from within (heterodox) economics. The economics of conventions starts out from the problem of uncertainty, posing the question of how actors coordinate their activities on markets. One of the uncertainties actors confront in markets stems from the contingency in the qualification of goods. Qualification refers to the development of shared cognitive and normative understandings of the qualities of the products exchanged. The approach stipulates that shared understandings of product qualities emerge through processes of interaction in the market field, processes which lead to the formation of conventions. Conventions allow that actors base their expectations and actions on joint knowledge. These emerging frames, however, are not homogeneous. On the contrary, conflicting "orders of worth" (Boltanski and Thévenot 2006) can be institutionalized simultaneously in 
a field, making it necessary for the actors to negotiate between them. This is an important source of the dynamics of valuation processes (Stark 2009). The theoretical framework of the economics of convention has been applied to evaluation processes in markets as distinct as the labor market (EymardDuvernay and Marchal 1997; Marchal and Rieucau 2010; Salais 1989), the wine market (Diaz-Bone 2005), and financial markets (Orléan 1999). Considered in systematic terms, the concept of conventions-like status, standards, judgment devices, circuits of commerce, or frame-is a response to the failure of neoclassical theory to explain preferences.

\section{Standard and Status Markets}

One of the most insightful vantage points when disentangling processes of product qualification is to observe what is actually being judged in the market. Intuitively, it seems to be obvious that it is the qualities of the product that are evaluated in relation to the qualities of other products in the market. However, this holds true for only one kind of market, which can be called the standard market (Aspers 2009). Standard markets are defined by the existence of a scale of evaluation for what is offered in the market that exists independently from the buyers and sellers. Buyers and sellers orient to this scale when evaluating goods. Gold markets as well as stock exchange markets are examples of standard markets.

The standard may be constructed by the market actors themselves, for example by an industry organization (Ahrne and Brunsson 2008) or by market intermediaries, or imported from outside, for instance when the state sets the standard. The applied measuring techniques are not simply "objective," but are deeply culturally (and politically) entrenched. The chapter in this volume by Marion Fourcade on the techniques used for the economic assessment of environmental damages shows an example of such entrenchment, as does the chapter by Akos Rona-Tas and Stefanie Hiss on credit rating agencies. ${ }^{11}$

(p.18) A status market, by contrast, lacks a scale of value that is independent of its actors. Instead, offers are evaluated with reference to the actors who offer or purchase the product or service. Buyers and sellers stand in rank order of interrelated status positions. The value of what is traded in this kind of market is a function of the participating actors. Stated in generalized terms, in status markets value is established as a consequence of activities that are oriented to the social status of the market actors. Actors shift "their orientation from what is exchanged to the social structural positions of their potential exchange partners" (Podolny 1994: 459). The social structure of the market is relatively more entrenched for the assessment of value than any scale measuring product qualities. Here, one can also see how evaluation and valorization are inseparably linked. 
Though the role of status can be relevant in all markets, it becomes especially visible for products where value reflects aesthetic judgments. Garments and modern art, and also cars, furniture, and wine provide examples of markets in which objective differences in quality can be established only partially or not at all. The fashion industry provides especially illuminating examples (Aspers 2010). The quality of a sweater is not assessed on the basis of a ranking of the material qualities of different sweaters; the categorization derives rather from the assessment of the status of the brand that is selling it. That we value a sweater from Armani so much more highly than one from H\&M is based on the known status order of brands in this industry. The value, however, can also derive from the status of the users, from who buys a certain product or label. Is the label "in" or "out" among purchasers who have high social status in the market?

The role of status for the value of products is investigated in Ashley Mears' chapter (Chapter 7) on the pricing of fashion models. Her starting point is the apparent arbitrariness of aesthetic evaluation that actors in this industry face. This leads to uncertainty regarding the value of the "look" to be sold, in the same way that the art market must confront the uncertainty of what establishes quality in art. The status of models in the market emerges, Mears argues, from a reputation that is gained by working for prestigious magazines and photographers, even though these jobs typically pay very badly or not at all. ${ }^{12}$

The relevance of status orders in markets is not limited to consumer markets. Joel Podolny, for example, investigated the prices that investment banks charge their clients when underwriting corporate securities and has (p.19) shown the correlation of price and status in this market (1994). One implication deriving from the measurement of quality according to status is that value cannot be separated from social practices. What is "high status" and what is "low status" is the result of definitional struggles taking place in the market field. Such struggles involve not just customers and the supplying firms but also many intermediaries such as critics, designers, and traders.

\section{Judgment Devices}

The valuation of goods takes different routes in standard markets and status markets. ${ }^{13}$ Both types of markets, however, converge in that social devices allow for the categorization of different offers in the market and thereby reduce uncertainty. Standards and status assessments can be described as two principles of categorization of goods allowing for the ordering of offers in markets. But how are standards set, and how is status assessed?

In recent years, several studies anchored in the field of the social studies of finance have analyzed the role of mathematical models as devices for the assessment of the value of financial products. An important basis for this was laid by Michel Callon, who introduced the notion of "calculative tools" (Callon 
1998). Calculation of equivalence in financial markets takes place through formulas and accounting rules. Such technologies of valuation have been analyzed by Donald MacKenzie and Yuval Millo (2003), for instance, in their now classic article on the Black-Scholes model of derivatives pricing and its role in making possible the expansion of the derivatives market since the 1970s. More recently, Donald MacKenzie has analyzed the evaluation practices of rating agencies when assessing the risks entailed in collateralized debt obligations (CDOs) and asset-backed securities (MacKenzie 2010). MacKenzie discusses the role of the mathematical formula known as the Gaussian copula that has been used to calculate the risks of the CDOs, and relies on a correlation number that expresses the interdependencies of the securities pooled in one CDO. The formula made it possible to calculate the risks. The low levels of correlation assumed in the models, however, made the securitized debt look much less risky, and hence more valuable, than it turned out to be.

While such calculative tools have seized the attention of scholars in the field of social studies of finance, the French sociologist Lucien Karpik developed a conceptual framework of the mechanisms applied to assess quality in markets for "singular goods" (Karpik 2010). Karpik calls these mechanisms judgment devices. With this notion Karpik refers to "guideposts for individual and collective action" (Karpik 2010: 44), which dissipate the opacity of the market by reducing the cognitive deficits of market actors engendered by their incomplete knowledge of products and by providing reasons for choices. Judgment devices create order in markets by flagging out differences in the (p.20) quality of products and between the status of producers. Karpik's contribution consists of proposing a typology that entails a large spectrum of different devices through which judgments of products offered on the market are shaped. While this might not be an exhaustive typology of the devices to classify goods and producers, much of the research in economic sociology on the classification of goods refers to one or several of these devices.

1. Personal networks refer to the social structure of the demand side. Personal networks provide actors with credible and trustworthy information. When selecting professional services from doctors, lawyers, or accountants, people rely on the contacts that make up their personal networks. They act according to information they receive from personal sources they trust. The use of networks of friends or colleagues as guides for quality assessments, which sometimes is called social capital, is common in markets in which actors only infrequently operate and in which the value of the commodity exchanged is not easily measured (Powell 1990).

2. Karpik uses the term cicerones to refer to critics and guidebooks that "embody a soft, symbolic form of authority" (Karpik 2010: 46) and thereby influence the evaluation of the qualities of different offers. These can be travel guides, car magazines, or restaurant guides that steer 
actors who are choosing a restaurant or a new car. Karpik himself has conducted a study on the role of the Guide Michelin in the French restaurant market (Karpik 2000). The Guide Michelin compares, selects, and rates restaurants. The notion of quality is defined by the Guide through Michelin's own judgment criteria. At the same time, the Guide leaves space for the heterogeneity of principles of worth that will be applied by different customers, by informing the reader through various categories.

Cicerones are also the experts in a market who shape judgments of the goods through their assessments. One example of a market where critics play an extraordinarily important role is the art market (Beckert and Rössel 2004; Velthuis 2005; Yogev 2010). Aesthetic markets (Aspers 2001: 1) generally have no objective standards by which quality could be measured and compared. Instead, quality is constructed from the judgments of the participating actors. As gallery owners, museum curators, art critics, collectors, or professors at art schools, these experts shape the evaluation of art works through their opinions, reviews, purchasing decisions, and exhibition policies. These authorities are carefully watched by the other actors in the field, who deduce the quality of an artist through the judgments of professionals (see also the chapter by Ashley Mears in this volume). In financial markets, analysts are experts who exercise a soft pressure on investment decisions through their assessments of the financial assets traded. ${ }^{14}$

(p.21) 3. Karpik uses the term confluences for the techniques used by firms to channel buyers, "ranging from territorial location, spatial organization and displays to selling skills" (Karpik 2010: 46). The role of confluences can be demonstrated with a recent study on the French funeral market. Pascale Trompette investigated how the organizational structures of the market influence the decisions of families in need of the provisions for a funeral (Trompette 2007). The principal judgment devices relevant in this industry are techniques used by firms to channel buyers. Opening up a funerel home right at the hospital-where most people die these days-puts these services in direct proximity to the families of the deceased. Hence, economic value is created through the location of suppliers. Another example would be the organization of the presentation of merchandise on the shelves in supermarkets.

4. Rankings include not only bestseller lists like the ones for music and books but also the rankings for academic journals, universities, hospitals, lawyers, or wine, which are often established by magazines. One market where rankings are highly influential judgment devices is the wine market. In contrast to the soft authority of cicerones that allows more than one principle of worth to be included, ranking is a way of creating order out of what is offered in a market by reducing complexity to one single scale at the ordinal level. Robert Parker introduced a scale that 
uses values between 50 and 100 to rank wines. This scale mimics an "objective" standard, though it is in essence subjective. Many studies on the wine market have confirmed the influence of the Parker ranking on the prices for wine (Gibbs et al. 2009; Hay 2007).

Wine has become a frequent object of studies on valuation (Benjamin and Podolny 1999; Diaz-Bone 2005; Hay 2010). In this volume, Marie-France Garcia-Parpet (Chapter 6) provides a case study on quality classification in the wine market. She focuses only indirectly on the influence of rankings and centers on the role a social network can play as a substitute for high rankings. Garcia-Parpet analyzes how the winemaker Aimé Guibert was able to establish a reputation as a high-quality vintner in the Languedoc-Roussillon region, a region with traditionally low status in the French wine market. Finding support in the Anglo-American wine press through his networks, Guibert was able to change how his product was perceived in assessments from the wine press, and even contributed to the re-evaluation of the status of the region itself. The chapter by Lucien Karpik in this volume (Chapter 3 ) deals with the assessment of scholarly success (p.22) through the ranking of academic journals. By asking "What Is the Price of a Scientific Paper?" Karpik, like Fourcade in her chapter, shows how mechanisms designed for the assessment of value in market exchange are dispersing into other social spheres.

The chapter by Akos Rona-Tas and Stefanie Hiss (Chapter 10) explores ratings in financial markets. Ratings differ from rankings by providing assessments of the probability of certain events but not positioning the good in relation to the performance of a set number of other goods. Rating agencies provide assessments of the quality of debt. The value of a loan is based on interest rates and assumed risks. Rating agencies deal with the second dimension: they evaluate the promises of borrowers to pay back their loans. The grade given to a security issued by a company, bank, or country is the measure that communicates the risks involved. These ratings might or might not deliver accurate predictions but they are the basis by which markets value the debt. The financial crisis, RonaTas and Hiss argue, was foremost a colossal failure of valuation. That the ratings themselves influence the value of the object rated shows how judgments do not just measure value but constitute it. Value is a result of interpretation and not an objective measure of an inherent quality.

5. Finally, appellations include all kinds of labels like designations of origin, certifications, brands, and professional titles. They are signals of quality scrutinized by independent third parties. Classifications like the Appellations d'Origine Contrôlée, which certify that a product is of a certain origin and produced according to certain standards, are ways of categorizing offers at the nominal level. Roquefort cheese and champagne are products that are labeled according to their place of origin. Appellations, however, refer not only to places of origin for 
products but also to production standards. Lumber that is certified as having been sustainably logged (Maletz and Tysiatchniouk 2009) and fair trade products are examples of appellations that reference production standards. Fair trade products are valued not for a superior functional value but for the compliance with specific ethical standards in the production process. Though these differences in the production process are invisible in the product itself, some consumers are valuing the products more highly and are willing to pay a premium price for them. Peter Gourevitch (Chapter 4) investigates certification in fair trade markets. Gourevitch is especially interested in the issue of monitoring, which is particularly pressing in ethical markets. Since the products are not different materially, how can producers convince their customers of the truthfulness regarding their claims of compliance with the ethical standards, that is, the value of their product?

While brands are established by firms, certificates and designations of origin are standards that are set and controlled by associations or the state. Though appellations per se do not create rank orders between different regions, for example, singling out a region enables product differentiation, (p.23) branding, and niche creation to occur at the level of markets instead of firms (White 1981). Appellations reduce uncertainty in the market but also lead to collective monopolies.

Research in economic sociology on calculative tools and judgment devices has taken a perspective that is largely rooted in science studies and in cultural sociology. It is crucial to integrate political sociology much more strongly into this perspective, emphasizing the power-laden political struggles leading to the use of specific judgment devices. If value depends on the contingent assessment of product qualities, the classification of goods is part of a market struggle. There is a politics of classification led by rent-seeking actors (Buchanan et al. 1980). The classification of goods is not just a matter of coordination but also of distribution (Beckert 2009a).

The Organizational Basis of Value

The formation of criteria used to assess the quality of goods can emerge spontaneously in the market, developing gradually into taken-for-granted conventions that are used to judge products. Often, however, established criteria for product qualities have their origin in organizational action. Markets are populated by firms, either on one side (such as in the labor market or a final consumer market) or on both sides (business-to-business markets). Studies on valuation in markets demonstrate the crucial role organizations play through their identities (White 2008), their positioning of products in the market (Power and Hauge 2008), their creation of standards (Brunsson and Jacobsson 2000), and their introduction of judgment devices. Organizations play a role in valuation processes not only through the design of market devices but also through the positioning of products under the given regime of devices prevailing 
in the market. Firms attempt to attach customers to products even as they struggle to detach customers from the products of their competitors. "In the economy of qualities, this struggle for attachment and detachment is at the heart of competition" (Callon et al. 2002: 207).

Though this does not imply that processes of valuation of products can be read as a story of manipulation through powerful producers, organizations have the advantage over individuals in that they command collective resources.

Organizations also play an important role as market intermediaries, as in the case of rating agencies. Not all organizations in markets are firms.

Nongovernmental organizations and consumer associations (Micheletti 2003) also play a role in the valuation of objects, for instance when they monitor claims by producers of ethical production practices, as shown in the chapter by Peter Gourevitch. It is therefore important to take into account how organizations act in markets to affect what is valued and how it is valued.

Some of the most interesting work on the relationship between organization and value in markets has been done by David Stark (2009). In a set of (p.24) meticulously researched ethnographic studies, Stark focuses on the organization of work practices for the creation of worth in production processes. In one of his ethnographies, a study on a trading room in Manhattan's financial district, Stark analyzed the spatial distribution of the work places of traders and analysts in the trading room to show how work organization is designed to increase the chances of traders to discover trading opportunities. Traders following different trading strategies are positioned in the room in ways that allow them to interact easily. This creates a morphology prone to "creative disturbances," and an organizational form which Stark calls heterarchy.

Other studies on the relationship of organization and economic value stress the crucial role of practices as well. Value emerges from practical activities, including discourses within the firm or between the firm and its competitors or customers (Ansari and Munir 2008; Mützel 2009). In this volume, Davide Ravasi, Violina Rindova, and Ileana Stigliani (Chapter 13) address the relationship of organizations and valuation in an empirical study on corporate museums. Firms whose products are especially valued for the symbolic meanings they carry for customers must themselves maintain a precise "feeling" for these symbolic connotations in order to be able to design and market products that fulfill the expectations of their customers. Corporate museums, Ravasi, Rindova, and Stigliani show, have the function not only to sustain the "myth" of the product as a form of symbolic value in the perception of (potential) customers who visit the museum but also to maintain this myth in the cognitive frame of the employees and thereby in their work practices. 


\begin{abstract}
Value through Friction
Much of the debate in economic sociology on processes of valuation deals with social devices as a basis for individual judgments of products and for the intersubjective congruence of quality judgments in the market. Such a perspective, however, finds its theoretical limit in the functioning of markets themselves. Though valuation is a socially structured process, a theoretical conceptualization of the valuation of goods must allow for the diverse assessment of qualities by different actors and the simultaneous existence of several possibly contradictory devices. If action is seen as simply conforming to market devices, this leads to an overly static assessment of valuation processes that does not do justice to the dynamic changes of the evaluation of goods and assets. Especially in capitalist economies, the rapid change of the evaluation of products-whether financial assets or consumer goods-is not only empirically observable but also a central element of their growth dynamics. How can one incorporate the dynamics of value in a theoretical model?
\end{abstract}

Several approaches dealing with questions of valuation have attempted to comprehend the dynamics of the value of economic goods. In the analysis of (p. 25) consumer markets, Georg Simmel was the first to recognize what was later referred to as the trickle-down effect (1971). Simmel observed that once clothing designs that are valued by the upper classes for their representation of social status have found their way to the lower social classes, these designs become devalued in the eyes of the upper classes because the clothes no longer signal social distinction. The distinction is reestablished through the change in fashions among the upper classes. This never-ending process feeds a constant cycle of valuation and devaluation in fashion markets. ${ }^{15}$

In Simmel's days branding was not central, which might explain why he gave so little attention to the role of producers in understanding the dynamics of value. This changed through studies such as Michel Callon's (Callon et al. 2002). The dynamic mechanism Callon describes is not the competition between customers struggling for social distinction but the struggle of firms for profits. In contrast to the trickle-down effect, the mechanism of competition locates the source of the dynamics of valuation on the supply side of markets even if customers are involved in the processes.

David Stark (2009) offers a still different perspective. Stark focuses on the deviation from established routines and scripts in valuation and the deviation from the use of established judgment devices that reduce uncertainty. He argues that value does not derive from following conventions. Quite the contrary: for Stark, value emerges from the deviation from routines and devices. Very close to the Schumpeterian notion of the entrepreneur as the type of actor in the economy who breaks with routines and establishes new combinations, Stark argues that worth emerges from "the ability to keep multiple evaluative principles in play and to exploit the resulting friction of their interplay" (2009: 
15). Firms discover what is valuable through the interplay among different assessments of value that exist simultaneously in one organizational setting and produce "productive frictions." This theoretically important reflection has its background also in the notion of "orders of worth" (Boltanski and Thévenot 2006).

By emphasizing dissonance over interpretative agreement between actors, Stark stands in opposition to large parts of the sociological literature on valuation in the economy that emphasize the need to reduce this uncertainty through market devices. Stark's position might be exaggerated because he takes order in markets too much for granted, without explaining how order is established from organizational friction. New opportunities are always discovered from the background of established routines, scales, status orders, and judgment devices (Beckert 1999). The principal point is nevertheless highly relevant, especially in the context of dynamic capitalist economies (see also Moeran and Pedersen 2011). The relationship between intersubjective agreement on the one hand and differences between actors in the valuation of objects on the other is a vital theoretical issue in the field.

(p.26) In financial markets and investments in capital goods, the interest of actors-as we have described above-is in future value. To realize future value, actors must take risks in largely unpredictable environments. Profit-that is, realized future value-does not result from following established routines but from creative recombinations whose potential has not yet been exploited by others. In this volume, it is Charles Smith (Chapter 12) who takes up the idea of deviating from established script as a condition for creating value. In his chapter on the decision-making of traders in financial markets, Smith argues that decisions on assessments of what is valuable emerge from practices of interpreting conflicting information. Smith introduces the notion of "acting sensibly" and contrasts this with a decision style he calls "making sense." When traders are managing their positions, meanings, according to Smith, are "emerging from practices rather than guiding these practices" (Smith in this volume).

While Smith remains less specific about the action-theoretic foundations of "acting sensibly," David Stark develops his understanding of the discovery of worth on explicit action-theoretic grounds (2009). Stark proceeds from John Dewey's notion (1998) of inquiry as a specific mode of action in situations where routines break down and actors are confronted with troubled and perplexed situations. Actors in these situations can only respond to them through social practices in which they discover an understanding of the problem, and possible solutions to it, through processes of trial and error. This finding from Stark alludes to a more general point that was covered in the discussion of Michel Callon's work: valuation takes place in action. The social practices 
characterizing the valuation of goods, however, have no resemblance to the model of rational action even if actors are purely self-interested.

This is in part because in non-routine purchasing decisions, one can take neither actors' identities nor what is traded as a given. Both are co-constructed in the market process itself, and these processes affect the selves of the actors involved as well as the meaning of the goods exchanged. Actors bring values along when they enter the market, but they will also change their values as a result of being in the market. This implies that at least at the outset, actors' meaning is not directed to specific goals, not least because the problems involved in the valuation of products are not even understood at the beginning. This lack of fixed values at the outset stresses the practical activities of actors, their interpretations, and their construction of meaning. Value and preferences can only be understood in relation to the very social processes in which they are already applied.

The fact that value emerges at least in part from interpretation also shows that innovative activities are not limited to process or product innovations but also emerge from cognitive reconfigurations of existing goods (Thompson 1979). In principle, this is an unlimited source of value. At the same time, it points to the fragility of value in the economy. What would happen to the car industry, for instance, if consumers began to see cars as nothing but profane (p.27) means of transportation, disconnecting the product from the dream worlds symbolically represented in it?

\section{Value and Prices}

So far, the discussion has focused mostly on value and processes of valuation in markets. But what about price? Value and price differ, but markets establish economic value in the form of prices, both as a result of people coming together to trade and as an outcome of a specific institutional structure. Each market actor may have an idea of how a certain object or service should be valued in monetary terms because of its beauty, purity, might, or high or low moral standing. All of these values are forced into a single scale when they are ordered according to the money that one would be willing to pay. The amount a person is willing to pay for a good or is willing to sell it for is equal to its economic value from the perspective of the individual market participant.

Market price is not the same as economic value. The market price is the outcome of different assessments of the economic value of a product in the market process. The market price can differ from the economic value individual actors assign to the product in terms of what they would be willing to pay. Market prices, however, are at the same time the outcome of the social structure of the market, of the prevailing institutional rules, networks, and conventions (Bourdieu 2005; Fligstein 2001). Prices result from "the established rules of the game that producers tacitly obey" (Velthuis 2005: 10). 
While prices are numerical values assigned to a good, it is important to distinguish between different forms of price. There is price setting (price quoting), set price, and market price. Price setting refers to the process by which offering prices are determined; the set price is the price at which the product is offered; and the market price is the monetary value for which the good changes hands. Set prices have a wider role than to tell purchasers the amount of money for which they can purchase the product. Set prices also act as signals that provide orientation in markets, enabling comparisons within a market and across markets (Schnabel and Storchmann 2010; Spence 2002). Prices are information in a communication process (Luhmann 1988: 18).

In a way, it is ironic to reintroduce the distinction between price and value, since the essential shift of marginal utility theory was to abandon the notion of value altogether and focus exclusively on price. A closer look makes it apparent, however, that to understand markets one must introduce a notion of value that stands apart from price. Prices do not inform customers as long as the customer does not have a standard from which to judge them. The price information itself does not tell the actors what to do in the situation (Luhmann 1988: 20). Calling a product "expensive" or "cheap" is only possible based on the assessment of the price in relation to the assessment of the worth of (p.28) product qualities: Without some notion of value, independent of price, there would be no way to judge prices. This important relation between price and value alludes once more to the point that a theory of exchange, as offered by neoclassical theory, does not in itself suffice to explain the operation of markets and must be complemented by a theory of valuation (Vatin 2009: 16). A remnant of this problem can be detected in neoclassical economics in the notions of "consumer surplus" and "producer surplus."

Hence, the thorny question becomes how prices emerge and change. While supply and demand do influence prices, the question remains where this supply and demand stems from. The answer refers to the social contexts of valuation of goods and assets. Demand is patterned by the processes described above, in which actors constitute the worth of goods by assessing the goods' functional and symbolic qualities, applying judgment devices, and noting their position in the market structure. Supply and demand are the result of the social structuring of markets through institutions that regulate competition (Bourdieu 2005), power structures between buyers and sellers (Marx 1977), social networks (Ingram and Roberts 2000; Podolny 2005; Uzzi and Lancaster 2004), and cognitive frames (Velthuis 2005), which shape the demand for goods and the ways in which firms compete with each other (Fligstein 2001). Hence, "prices are not something that mysteriously emerges from 'the market.' They are part of the terms-of-trade and are socially constructed by the actors involved in the exchange" (White and Eccles 1987: 985). ${ }^{16}$ 
Prices also depend on the price mechanism used. In the auction market, price is the outcome of a process of bidding among buyers (Smith 1989). In most markets, prices are set by the seller and are not subject to market negotiations. Different forms of markets have different ways of generating prices. Interest in economic sociology has been especially devoted to various forms of auction markets (Garcia-Parpet 1986; Smith 1989; Velthuis 2005). Though there is variation between these auction markets, they are all forms of the market type that Léon Walras theorized based on his observation of the Paris stock exchange. How can we theoretically assess the selection of the price mechanism in a market? In this volume, Olav Velthuis (Chapter 8) deals with this question by addressing the issue of which forms of sale in the art market are considered legitimate. While economic theory would expect that auctions are used above all in the primary art market (Smith 1989), because of the high uncertainty associated with the novel products, and that the sale with fixed prices through galleries would prevail in the more established secondary (p.29) market, the reality is exactly the opposite. Auctions in fact hardly ever occur in the primary market. Velthuis explains this empirical observation based on conventions of how to legitimately sell art. These conventions are an important structural component of the constitution of worth. Velthuis therefore provides an example of the cultural embeddedness of price mechanisms in the economy. The globalization of the art market that is evident from the entry of countries like China into the market, however, might also challenge such entrenched conventional practices.

Most transaction prices are not the outcome of auctions or of negotiation between suppliers and customers, but are set by the supplier, so that prices emerge from firms. This leads once again to the connection between the sociology of markets and organizational sociology. We find an example of price setting by firms in the producer markets discussed by Harrison White (White 1981); firms carve out a niche, a process in which price setting is crucial. To understand set prices in markets, it is important to understand the market positions and the identities of the firms, while also looking closely at what goes on inside the firm. How are prices calculated?

There is very little research in economic sociology on pricing practices. One of the few exceptions is the work by Mark Zbaracki, who investigated price setting strategies in a large industrial firm (2004). Zbaracki shows that set prices are the outcome of negotiations between different groups within the firm, each attributing different meanings to prices and pricing strategies. The uncertainty regarding optimal strategies makes pricing a process of negotiation, wherein the social order in the organization is "constructed in the ongoing interactions" (Zbaracki 2004: 3). The rationale of economic price theory plays a very important role in this process. But rather than determining prices, the theory holds influence because of its use by some actors as a reference point for 
legitimating their positions: "Price theory may serve as a rational myth" used by actors to make sense of a situation (Zbaracki 2004: 17).

Finally, we must include the interrelations between price and value in the understanding of price. Prices are not only influenced by the contingent valuations of products by customers but are also reconnected to the valuation process. This is the case when the value actors assign to products is dependent on the products' set price (Schnabel and Storchmann 2010). Customers may interpret the set prices as a quality signal from which they may form their value judgment. A special case of this phenomenon is when customers value a product more highly because of its high price, a phenomenon that is especially observable in the markets for luxury products. In the luxury case, price becomes itself a judgment device in the market. This also implies that it is wrong to conceptualize the process of bestowing value as unidirectional. Using the example of the art market, one causal link would be that we first have a painting, then a value assessment, and finally a price for the painting. Theoretically, assuming that the object has no inherent value, our reasoning could also start with a high price and an expert's assertion of the object's value, which would lead to "art" with high value. In other words, it is essential to see (p.30) the interconnectedness of price, value, and the object in the market process. This does not deny that the costs associated with the production of goods influence their price. It shows, however, that the object in the market becomes what it is as a result of the value bestowed by market actors, of which price can be one source.

Valuation and Pricing on Markets: Lines of Research Understanding the valuation and pricing of goods is one of the main tasks for economic sociology. The coordination of economic exchange through markets can only be understood if it is made apparent how market actors value goods and assets. Markets fail if the problem of valuation cannot be resolved. Over the last 30 years, a number of instructive studies have been published on these topics from different perspectives. Some of the most interesting work on the issue has been done by French sociologists and economists, but in many cases neither this work nor its authors have found the recognition they deserve outside of France. ${ }^{17}$ The field would gain immensely if it were better at overcoming national and language barriers.

Studies on valuation and pricing have provided often fascinating ethnographies of the empirical cases investigated. The empirical scope has chiefly concentrated on three types of markets: first, financial markets (MacKenzie and Millo 2003; Stark 2009; Rona-Tas and Smith, both in this volume); second, markets for aesthetic goods, such as fashion (Aspers 2010), wine (Benjamin and Podolny 1999; Diaz-Bone 2005), art (Beckert and Rössel 2004; Velthuis 2005; Yogev 2010), and food (Dubuisson-Quellier 2003); third, markets in which ethical issues figure prominently, such as the markets for life insurance (Zelizer 1979), 
whale watching (Lawrence and Phillips 2004), and fair trade products (ZickVarul 2009). These three types of markets hold a special attraction for sociologists because value seems detached from the materiality of the commodity and in very obvious ways socially constructed. In financial markets, value hinges on mathematical formulas (MacKenzie and Millo 2003; Rona-Tas and Hiss in this volume) and sometimes on speculative frenzies expressing the herding behavior of actors. In aesthetic markets, the assessment of value is the result of contingent judgments of aesthetic quality in the market field. In the case of products valued for their moral qualities, the social basis of their valuation is already part of the definition of the object studied. It is on the basis of these markets that certain mechanisms in the construction of value and price can be especially well depicted, allowing the researcher to identify (p.31) general mechanisms that can also be applied to markets for industrial goods and consumer goods more generally.

The types of markets investigated in sociological studies on valuation gain further empirical significance in contemporary economies. The financialization of the economy (Froud et al. 2009) has increased the importance of financial markets during the last 30 years. Increasing product differentiation in functionally saturated markets has also led to the growing importance of moral and aesthetic criteria in the marketing of products (Rössel 2007; Stehr 2007). Today we can also find elements of aesthetic or moral judgments as part of product valuation in many markets where the functionality of the product used to be paramount: telephones, refrigerators, electronic equipment-everything from television sets to mobile phones and Apple computers. This is an important historical transformation of the structure of the economy that will have crucial consequences for sources of future growth but is also associated with the emergence of new risks, which are social in character. Value that hinges largely on symbolic meaning structures is vulnerable because attachments of consumers and investors can shift rapidly.

The study of markets like the wine market, where the social construction of value is especially apparent, allows for the identification of general principles. The next step, however, would be to focus studies on core industrial markets, whose relevance for the economy is still paramount even if it is receding. Much of the economy consists of airplanes, power plants, pork bellies, screws, and workers. ${ }^{18}$ A sociologically informed theory on valuation and pricing must aim at a general theory applicable to all market exchanges. Can the theoretical findings on value constitution, deduced from the study of wine, art, and finance, be applied to the study of other types of markets? Or do valuation processes differ systematically in different types of markets and, if so, how?

This broader empirical scope will also be necessary for advancing theory construction. The current state of research on valuation and pricing shows many interesting theoretical concepts. Among them are the notion of judgment 
devices, the distinction between standard markets and status markets, the concept of singularity, and the notion of heterarchy. Moreover, the existing research shows how different types of social structures such as networks, institutions, conventions, and cultural frames play a role in the valuation and pricing of products. Some research has also addressed the question of how these structures actually play out in the action process, hence focusing attention on social practices and laying the groundwork for a microfoundation of the sociological investigation of value. What is still missing is a general sociological theory of valuation and pricing of goods.

(p.32) The chapters of the volume provide empirical case studies as well as conceptual advances. The book begins by dealing with value in a broader sense: the first section is entitled "What is Valuable?," and the chapters by Fourcade, Karpik, Gourevitch, and Beckert discuss moral values, their formation, and the relations between economic and noneconomic values. The second section brings up the problem of valuation in aesthetic markets. The chapters by Garcia-Parpet, Mears, Velthuis, and Hutter all shed light on how value is created and established in markets for wine, fashion models, and art. The third section brings together texts that analyze financial markets. Rona-Tas and Hiss study the role of credit rating agencies, and Yenkey and Smith look at the formation of value in stock exchange markets. The final chapter by Ravasi, Rindova, and Stigliani connects the discussion of aesthetic value with organizational aspects of industrial production. The book ends with a comment from David Stark.

References

Bibliography references:

Ahrne, G. and Brunsson, N. (2008). Meta-Organizations. Cheltenham: Edward Elgar.

Akerlof, G. A. (1970). The Market for "Lemons": Quality Uncertainty and the Market Mechanism. Quarterly Journal of Economics 84: 488-500.

- - and Kranton, R. E. (2010). Identity Economics: How Our Identities Shape

Our Work, Wages, and Well-Being. Princeton, NJ: Princeton University Press.

Ansari, S. and Munir, K. (2008). How Valuable Is a Piece of the Spectrum? Determination of Value in External Resource Acquisition. Industrial and Corporate Change 17: 301-33.

Appudarai, A. (1986). The Social Life of Things: Commodities in Cultural Perspective. New York, NY: Cambridge University Press.

Aspers, P. (2001). A Market in Vogue: Fashion Photography in Sweden. European Societies 3: 1-22. 
—- (2009). Knowledge and Value in Markets. Theory and Society 38: 111-31.

- - (2010). Orderly Fashion: A Sociology of Markets. Princeton, NJ: Princeton University Press.

- - (2011). Markets. Cambridge: Polity Press.

- - and Beckert, J. (2008). Märkte. In A. Maurer (ed.), Handbuch der Wirtschaftssoziologie. Wiesbaden: VS Verlag.

Becker, H. (1982). Art Worlds. Berkeley, CA: University of California Press.

Beckert, J. (1996). What Is Sociological about Economic Sociology? Uncertainty and the Embeddedness of Economic Action. Theory and Society 25: 803-40.

- - (1999). Agency, Entrepreneurs and Institutional Change: The Role of Strategic Choice and Institutionalized Practices in Organizations. Organization Studies 20: 777-99.

- - (2009a). Koordination und Verteilung: Zwei Ansätze der Wirtschaftssoziologie. In S. Nyssen and G. Voruba (eds.), Die Ökonomie der Gesellschaft. Wiesbaden: VS Verlag.

- - (2009b). The Social Order of Markets. Theory and Society 38: 245-69.

(p.33) - - and Rössel, J. (2004). Kunst und Preise. Reputation als Mechanismus der Reduktion von Ungewissheit am Kunstmarkt. Kölner Zeitschrift für Soziologie und Sozialpsychologie 56: 32-50.

Benjamin, B. A. and Podolny, J. M. (1999). Status, Quality and Social Order in the California Wine Industry. Administrative Science Quarterly 44: 563-89.

Beunza, D. and Garud, R. (2005). Securities Analysts as Frame-Makers. Universitat Pompeu Fabra Economics and Business Working Paper No. 733. Barcelona: Universitat Pompeu Fabra.

- - and - - (2006). Frame-Making: An Interpretive Approach to Valuation Under Knightian Uncertainty. Working Paper. New York, NY: Columbia University.

Biggart, W. N. and Beamish, T. (2003). The Economic Sociology of Convention, Habit, Custom, Practice, and Routine in Market Order. Annual Review of Sociology 29: 443-64.

Binder, M. and Niederle, U. M. (2007). Institutions as Determinants of Preference Change: A One Way Relation? Paper on Economics and Evolution 0607. Jena: Evolutionary Economics Group, Max Planck Institute of Economics. 
Boltanski, L. and Thévenot, L. (1991/2006). On Justification, Economies of Worth. Princeton, NJ: Princeton University Press.

Bourdieu, P. (1984). Distinctions: A Social Critique of the Judgement of Taste. Cambridge, MA: Harvard University Press.

-_ (1992/1996). The Rules of Art: Genesis and Structure of the Literary Field. Palo Alto, CA: Stanford University Press.

- - (1983/2001). The Forms of Social Capital. InM. Granovetter and R. Swedberg (eds.), The Sociology of Economic Life. Boulder, CO: Westview Press, 96-111.

- - (2005). Principles of an Economic Anthropology. InN. J. Smelser and R. Swedberg (eds.), The Handbook of Economic Sociology. Princeton, NJ: Princeton University Press, 75-89.

Brunsson, N. and Jacobsson, B. (2000). A World of Standards. Oxford: Oxford University Press.

Buchanan, J., Tollison, R., and Tullock, G. (1980). Toward a Theory of the Rent Seeking Society. College Station, TX: Texas A\&M University Press.

Callon, M. (ed.) (1998). The Laws of the Markets. Oxford: Blackwell Publishers.

_- (2002). Pour en finir avec les incertitudes? Sociologie du travail 44: 261-7.

- - Méadel, C., and Rabeharisoa, V. (2002). The Economy of Qualities. Economy and Society 31: 194-217.

__ Millo, Y., and Muniesa, F. (2007). Market Devices. Oxford: Blackwell.

Carruthers, B. C. and Ariovich, L. (2010). Money and Credit: A Sociological Approach. Cambridge: Polity Press.

Chamberlin, E. (1933/1948). The Theory of Monopolistic Competition: A Reorientation of the Theory of Value. Cambridge, MA: Harvard University Press.

Deutschmann, C. (1999). Die Verheißung des absoluten Reichtums: Zur religiösen Natur des Kapitalismus. Frankfurt a.M.: Campus.

Dewey, J. (1938/1998). The Pattern of Inquiry. In The Essential John Dewey. Bloomington, IN: Indiana University Press, 169-79.

Diaz-Bone, R. (2005). Strukturen der Weinwelt und der Weinerfahrung. Sociologia Internationalis 43: 25-57. 
Djelic, M.-L. and Ainamo, A. (2005). The Telecom Industry as Cultural Industry? The Transposition of Fashion Logics into the Field of Mobile Telephony. InC. Jones and (p.34) P. H. Thornton (eds.), Transformation in Cultural Industries. Amsterdam: Elsevier JAI, 45-80.

Dodd, N. (1994). The Sociology of Money: Economics, Reason and Contemporary Society. Cambridge, MA: Polity Press.

- (2005). Reinventing Monies in Europe. Economy and Society 34: 558-83.

Douglas, M. and Isherwood, B. (1979). The World of Goods: Towards an Anthropology of Consumption. London: Routledge.

Dubuisson-Quellier, S. (2003). Confiance et qualité des produits alimentaires: une approche par la sociologie des relations marchandes. Sociologie du travail 45: 95-111.

Durkheim, E. (1893/1984). The Division of Labour in Society. London: Macmillan.

-_ and Mauss, M. (1902/1963). Primitive Classifications. Chicago, IL: University of Chicago Press.

Elster, J. (1983). Sour Grapes: Studies in the Subversion of Rationality. Cambridge: Cambridge University Press.

Espeland, W. N. and Stevens, M. (1998). Commensuration as a Social Process. Annual Review of Sociology 24: 312-43.

Eymard-Duvernay, F. (1989). Conventions de qualité et formes de coordination: l'économie des conventions. Revue Economique 40: 329-59.

-_ (2002). Les qualifications des biens. Sociologie du travail 44: 267-72.

-_ and Marchal, E. (1997). Façons de recruter: le jugement des compétences sur le marché du travail. Paris: Editions Métailié.

Favereau, O. and Lazega, E. (2002). Conventions and Structures in Economic Organization. Cheltenham: Edward Elgar.

Fiss, P. and Kennedy, M. (2009). Of Porkbellies and Professions: Market Framing and the Creation of Online Advertising Exchanges. Presented at the Second International Conference on Institutions, Innovation and Space, Alberta School of Business, June.

Fligstein, N. (2001). The Architecture of Markets: An Economic Sociology of Twenty-First-Century Capitalist Societies. Princeton, NJ: Princeton University Press. 
François, P. (2008). Sociologie des marchés. Paris: Armand Colin.

Froud, J., Leaver, A., Johal, S., Nilsson, A., and Williams, K. (2009). Narratives and the Financialised Firm. InJ. Beckert and C. Deutschmann (eds.), Wirtschaftssoziologie. Sonderheft 49 der Kölner Zeitschrift für Soziologie und Sozialpsychologie. Wiesbaden: VS Verlag.

Garcia-Parpet, M.-F. (1986). La construction sociale d'un marché parfait: le marché au cadran de Fontaines-en-Sologne. Actes de la recherche en sciences sociales 65: 2-13.

Gibbs, M., Tapia, M., and Warzynski, F. (2009). Globalization, Superstars, and Reputation: Theory \& Evidence from the Wine Industry. Journal of Wine Economics 4: 46-61.

Graeber, D. (2001). Toward an Anthropological Theory of Value. New York, NY: Palgrave.

Granovetter, M. (1974/1995). Getting a Job: A Study of Contacts and Careers, 2nd ed. Cambridge, MA: Harvard University Press.

-_ and Swedberg, R. (eds.). (1992). The Sociology of Economic Life. Boulder, CO: Westview Press.

Hay, C. (2007). Globalisation and the Institutional Re-Embedding of Markets: The Political Economy of Price Formation in the Bordeaux en Primeur Market. New Political Economy 12: 185-210.

(p.35) - - (2010). The Political Economy of Price and Status Formation in the Bordeaux en Primeur Market: The Role of Wine Critics as Rating Agencies. Socio-Economic Review 8(4): 685-707.

Healy, K. (2006). Last Best Gifts: Altruism and the Market for Human Blood and Organs. Chicago, IL: University of Chicago Press.

Ingham, G. (2004). The Nature of Money. Malden, MA: Polity Press.

Ingram, P. and Roberts, P. (2000). Friendship among Competitors in the Sydney Hotel Industry. American Journal of Sociology 106: 342-87.

Jagd, S. (2007). Economics of Convention and New Economic Sociology: Mutual Inspiration and Dialogue. Current Sociology 55: 76-91.

Karpik, L. (2000). Le Guide rouge Michelin. Sociologie du travail 41: 369-90.

- - (2010). Valuing the Unique: The Economics of Singularities. Princeton, NJ: Princeton University Press. 
Koçak, Ö. (2003). Social Orders of Exchange: Effects and Origins of Social Order in Exchange Markets. PhD thesis. Palo Alto, CA: Stanford University.

Lawrence, T. B. and Phillips, N. (2004). From Moby Dick to Free Willy: MacroCultural Discourse and Institutional Entrepreneurship in Emerging Institutional Fields. Organization 11: 689-711.

Leibenstein, H. (1950). Bandwagon, Snob, and Veblen Effects in the Theory of Consumers' Demand. Quarterly Journal of Economics 64: 183-207.

Lichtenstein, S. and Slovic, P. (eds.). (2006). The Construction of Preference. Cambridge: Cambridge University Press.

Lounsbury, M. and Rao, H. (2004). Sources of Durability and Change in Market Classifications: A Study of the Reconstitution of Product Categories in the American Mutual Fund Industry, 1944-1985. Social Forces 82: 969-99.

Luhmann, N. (1988). Die Wirtschaft der Gesellschaft. Frankfurt a.M.: Suhrkamp.

MacKenzie, D. (2010). The Credit Crisis as a Problem in the Sociology of Knowledge. Working Paper. Edinburgh: University of Edinburgh.

- - and Millo, Y. (2003). Constructing a Market, Performing Theory: The Historical Sociology of a Financial Derivatives Exchange. American Journal of Sociology 109: 107-45.

Maletz, O. and Tysiatchniouk, M. (2009). The Effect of Expertise on the Quality of Forest Standards Implementation: The Case of FSC Forest Certification in Russia. Forest Policy and Economics 11: 422-8.

Malinowski, B. (1922). Argonauts of the Western Pacific: An Account of Native Enterprise and Adventure in the Archipelagoes of Melanesian New Guinea. London: Routledge.

Marchal, E. and Rieucau, G. (2010). Le recrutement. Paris: La Découverte. Marshall, A. (1920). Industry and Trade: A Study of Industrial Technique and Business Organization; and of Their Influences on the Conditions of Various Classes and Nations. London: Macmillan.

- - (1920/1961). Principles of Economics (9th variorum ed., 2 vols). Edited and annotated by C. W. Guillebaud. London: Macmillan and Co.

Marx, K. (1867/1977). Das Kapital: Kritik der politischen Ökonomie, Vol. 1, 12th ed. Berlin Dietz. 
McCracken, G. (1988). Culture and Consumption: New Approaches to the Symbolic Character of Consumer Goods and Activities. Bloomington, IN: Indiana University Press.

(p.36) Micheletti, M. (2003). Political Virtue and Shopping: Individuals, Consumerism, and Collective Action. New York, NY: Palgrave-Macmillan.

Moeran, B. and Pedersen, J. (eds.) (2011). Negotiating Values in the Creative Industries: Fairs, Festivals and Competitive Events. Oxford: Oxford University Press.

Musselin, C. and Paradeise, C. (2002). Le concept de qualité: où en sommesnous? Sociologie du travail 44: 256-60.

Mützel, S. (2009). Koordinierung von Märkten durch narrativen Wettbewerb. In J. Beckert and C. Deutschmann (eds.), Wirtschaftssoziologie. Sonderheft 49 der Kölner Zeitschrift für Soziologie und Sozialpsychologie. Wiesbaden: VS Verlag.

O’Neill, J. (2009). Market. InJ. Peil and van Staveren, I. (eds.), Handbook of Economics and Ethics. Cheltenham: Edward Elgar, 317-24.

Orléan, A. (1999). Le pouvoir de la finance. Paris: Odile Jacob.

_- (ed.) (1994/2004). Analyse économique des conventions. Paris: PUF.

Podolny, J. M. (1993). A Status-based Model of Market Competition. American Journal of Sociology 98: 829-72.

- - (2005). Status Signals: A Sociological Study of Market Competition. Princeton, NJ: Princeton University Press.

- - (1994). Market Uncertainty and the Social Character of Economic Exchange. Administrative Science Quarterly 39: 458-83.

Powell, W. W. (1990). Neither Market Nor Hierarchy: Network Forms of Organization. Research in Organizational Behavior 12: 295-336.

Power, D. and Hauge, A. (2008). No Man's Brand-Brands, Institutions, Fashion and the Economy. Growth and Change 39: 123-43.

Richins, M. L. (1994). Valuing Things: The Public and Private Meanings of Possessions. Journal of Consumer Research 21: 504-21.

Robbins, L. (1935). An Essay on the Nature and Significance of Economic Science. London: Macmillan. 
Rössel, J. (2007). Ästhetisierung, Unsicherheit und die Entwicklung von Märkten. In J. Beckert, R. Diaz-Bone, and H. Ganssmann (eds.), Märkte als soziale Strukturen. Frankfurt a.M.: Campus, 167-81.

Salais, R. (1989). L'analyse économique des conventions du travail. Revue Economique 2: 199-240.

- - and Thévenot, L. (eds.) (1986). Le travail: marchés, règles, conventions. Paris: INSEE-Economica.

Scheper-Hughes, N. (2004). Parts Unknown: Undercover Ethnography of the Organs-Trafficking Underworld. Ethnography 5: 29-73.

Schnabel, H. and Storchmann, K. (2010). Prices as Quality Signals: Evidence from the Wine Market. Journal of Agricultural and Food Industrial Organization 8: $1-21$.

Schneiberg, M. and Berk, G. (2010). From Categorical Imperative to Learning by Categories: Cost Accounting and New Categorical Practices in American Manufacturing, 1900-1930. Research in the Sociology of Organization: 31, 25599.

Simmel, G. (1904/1971). Fashion. InD. Levine (ed.), Georg Simmel on Individuality and Social Form. Chicago, IL: Chicago University Press, 294-323.

- - (1907/1978). The Philosophy of Money. London: Routledge.

Smith, C. (1989). Auctions: The Social Construction of Value. Berkeley, CA: University of California.

Spates, J. (1983). The Sociology of Values. Annual Review of Sociology 9: 27-49.

(p.37) Spence, M. (2002). Signaling in Retrospect and the Informational Structure of Markets. The American Economic Review 92: 434-59.

Stark, D. (2009). The Sense of Dissonance: Accounts of Worth in Economic Life. Princeton, NJ: Princeton University Press.

Stehr, N. (2007). Moral Markets: How Knowledge and Affluence Change Consumers and Products. Boulder, CO: Paradigm Publishers.

Steiner, P. (2010). La transplantation d'organes: un commerce nouveau entre les êtres humains. Paris: Gallimard.

- - and Vatin, F. (2009). Traité de sociologie économique. Paris: Presses Universitaires de France. 
Stigler, G. and Becker, G. S. (1977). De Gustibus Non Est Disputandum. American Economic Review 67: 76-90.

Thompson, M. (1979). Rubbish Theory: The Creation and Destruction of Value. Oxford: Oxford University Press.

Trompette, P. (2007). Customer Channeling Arrangements in Market Organization: Competition Dynamics in the Funeral Business in France. Revue française de sociologie 48: 3-33.

Uzzi, B. and Lancaster, R. (2004). Embeddedness and Price Formation in the Corporate Law Market. American Sociological Review 69: 319-44.

Vatin, F. (2009). Évaluer et valoriser: une sociologie économique de la mesure. Toulouse: Presses universitaires Mirail-Toulouse.

Veblen, T. (1899/1953). The Theory of the Leisure Class: An Economic Study of Institutions. New York, NY: New American Library.

Velthuis, O. (2005). Talking Prices: Symbolic Meanings of Prices on the Market for Contemporary Art. Princeton, NJ: Princeton University Press.

von Weizsäcker, C. C. (2005). The Welfare Economics of Adaptive Preferences. Preprint of the Max Planck Institute for Research on Collective Goods 2005/11. Bonn: Max Planck Institute for Research on Collective Goods.

Walzer, M. (1983). Spheres of Justice: A Defense of Pluralism and Equality. New York, NY: Basic Books.

Warde, A. (1994). Consumption, Identity-Formation and Uncertainty. Sociology 25: 878-98.

Weber, M. (1922). Wirtschaft und Gesellschaft: Grundriss der Sozialökonomik, III. Abteilung. Tübingen: Verlag von J. C. B. Mohr.

-_ (1946). From Max Weber: Essays in Sociology. Ed. by H. Gerth and C. Wright Mills. London: Routledge.

-_ (1904-1905/1968). The Protestant Ethic and the Spirit of Capitalism. London: Unwin University Books.

-_ (1921-1922/1978). Economy and Society: An Outline of Interpretive Sociology. Berkeley, CA: University of California Press.

Welskopp, T. (2010). Amerikas große Ernüchterung: Eine Kulturgeschichte der Prohibition. Paderborn: Ferdinand Schöningh. 
White, H. (1981). Where Do Markets Come From? American Journal of Sociology 87: 517-47.

- - (2008). Identity and Control: How Social Formations Emerge. Princeton, NJ: Princeton University Press.

- - and Eccles, R. (1987). Producers' Market. InJ. Eatwell, et al. (eds.), The New Palgrave: A Dictionary of Economic Theory and Doctrine. London: Macmillan, 984-6.

(p.38) Witt, U. (2001). Learning to Consume: A Theory of Wants and the Growth of Demand. Journal of Evolutionary Economics 11: 23-36.

Yakubovich, V., Granovetter, M., and McGuire, P. (2005). Electric Charges: The Social Construction of Rate Systems. Theory and Society 34: 579-612.

Yogev, T. (2010). The Social Construction of Quality: Status Dynamics in the Market for Contemporary Art. Socio-Economic Review 8: 511-36.

Zbaracki, M. J. (2004). Pricing Structure and Structuring Price. Philadelphia, PA: University of Pennsylvania.

Zelizer, V. (1979). Morals and Markets: The Development of Life Insurance in the United States. New York, NY: Columbia University Press.

- - (2004). Circuits of Commerce. InJ. C. Alexander, G. T. Marx, and C. L. Williams (eds.), Self, Social Structure, and Beliefs: Explorations in Sociology. Berkeley, CA: University of California Press, 122-44. http://www.appropriateeconomics.org/materials/circuits_of_commerce_-_zelizer.pdf (accessed September 15, 2010).

Zick-Varul, M. (2009). Ethical Consumption: The Case of Fair Trade. InJ. Beckert and C. Deutschmann (eds.), Wirtschaftssoziologie. Sonderheft 49 der Kölner Zeitschrift für Soziologie und Sozialpsychologie. Wiesbaden: Vs Verlag, 366-85.

Zuckerman, E. W. (1999). The Categorical Imperative: Securities Analysts and the Illegitimacy Discount. American Journal of Sociology 104: 1398-438.

\section{Notes:}

(*) For helpful comments on earlier versions of this introduction, we would like to thank Susanna Alexius, David Dequech, Pierre François, Kristina Tamm Hallström, Jörg Rössel, and the members of the research group on the sociology of markets at the Max Planck Institute for the Study of Societies.

$\left.{ }^{1}\right)$ Throughout this text, the term "good" is used interchangeably with the term product and comprises services as well. Goods can be consumption goods or capital goods. Except where otherwise indicated, we subsume financial assets 
under the notion of goods, though economists usually distinguish between goods markets and financial markets.

$\left({ }^{2}\right)$ The return of something else (usually money) for the property rights surrendered sets market exchange apart from gifts; the voluntary character of the exchange sets market exchange apart from robbery.

$\left({ }^{3}\right)$ A correlate is the market's price-setting function. A hierarchy may well have internal transfer prices, for example a purchase or sale between different departments, but these prices are not set under competition; to have competition, outside actors must be involved for comparison as well.

( $\left.{ }^{4}\right)$ Emile Durkheim alluded early on to the close connection between the values held in a community and the value of the objects exchanged on the market. His most important example of this connection was the value of labor. Durkheim lamented the low wages paid to workers, seeing them as a pathological deviation from the rule that the wage a worker obtains should reflect the value society sees in his labor (Durkheim 1984).

$\left({ }^{5}\right)$ Money can be any means of exchange that is valued in local communities, such as within the Kula ring (Malinowski 1922). But money of this kind has no clear exchange rate with other currencies and stands separate from other circuits of commerce (Zelizer 2004). Today, most monies are currencies (Dodd 2005). A currency like the euro is legal tender and has exchange rates with other currencies.

$\left({ }^{6}\right)$ Marx (1977), however, connects the value of a commodity to the "socially necessary labor time" for its production. This can be interpreted as an influence of market competition on the value of goods.

${ }^{7}$ ) The focus on subjective utility and on using the desire of actors as the basis for economic value does not imply that the costs of production-some of which are labor costs-are irrelevant. The production costs are relevant to the question of whether a product is produced at all. Only products whose expected price in the market is high enough to generate a profit for the producer will be produced. Hence, production costs influence market supply but the cost of production must not affect how market actors evaluate goods.

$\left({ }^{8}\right)$ More recently, some economists have broadened the utility function to also include noneconomic values. Akerlof and Kranton suggest that economists should account for who the actors are and how they want to live their lives, and have labeled this approach Identity Economics (Akerlof and Kranton 2010), an approach that also draws on sociological research.

$\left({ }^{9}\right)$ Endogenous changes of preferences (Lichtenstein and Slovic 2006) have been observed in situations where actors adapt their preferences to the situation 
-for instance, when actors declare that goals are no longer desired once they seem unreachable (Elster 1983). One challenge is to integrate such adaptive preferences into welfare theory (von Weizsäcker 2005). Another challenge is to explain the constitution of preferences. Some economists have suggested answers to this question based on psychological theories. Witt, for instance, has recommended a behaviorist theory of wants that distinguishes between innate wants and acquired wants, the latter of which can change over time (Witt 2001). Both types of wants can be expanded chiefly through new product designs and the instruments of marketing. Other economic approaches dealing with the constitution of preferences may take into account the desire for social integrity (acting cooperatively and fairly), for example, or the beliefs and evaluations of actors as they are expressed in attitudes toward goods (Binder and Niederle 2007).

$\left({ }^{10}\right)$ Symbolic and relational value overlap if the possession of goods contributes to the social identity of the owner. Value is symbolic, but not relational, if the satisfaction does not derive from recognition by third parties, as in the case of the amazement experienced in a theatre performance. Value is relational, but not symbolic, if the relational part refers to the use value of the good. A father buying a pair of shoes for his daughter's hiking trip would be an example.

$\left.{ }^{11}\right)$ What is not yet clear is how the object is economically rated, meaning how it gains an economic value in the form of price. The standard is independent of the price setting of what is traded in the market. Regardless of the price of one kilo of silver, the determination and rating of silver as silver is unaffected. We will come back to this when discussing the relationship of value and price.

(12) This demonstrates an interesting paradox of separation of reputation from (immediate) financial rewards. One can assume a mechanism operating here that is also found in the art world (Becker 1982; Bourdieu 1996): artistic value and monetary value stand in a hostile relationship to each other; the obscuring of the monetary dimension aims to protect the "sacred" character of the product that is in danger of being contaminated by money. As Viviana Zelizer has argued, we may speak of circuits of commerce, each of which has its own logic, media of exchange, and clear boundaries against the others (2004). The actors in such a circuit share meanings. In some circuits, money will hence be seen as hostile or immoral, or as damaging to the dignity of the activity or person (O’Neill 2009).

$\left({ }^{13}\right)$ In any market, however, standard and status can be empirically intermingled as a means to order markets.

${ }^{(14)}$ In the financial markets as well as in the art market, one can observe that the influence of these experts depends on their status. Financial analysts can become stars in the field if they have made accurate forecasts in the past, giving their judgments much greater weight compared to other analysts. It makes a 
crucial difference for the artistic and economic value of an artist whether his or her work is exhibited at the Centre Pompidou or at a local gallery, or whether it is a renowned art critic or a local journalist who reviews the work. The bestowal of value cannot be separated from the activities and voices of actors in the field who have status, and who therefore are in the structural position to define "value."

(15) See also Djelic and Ainamo, who show in an excellent article how the telephone industry has attempted to imitate the business model of the fashion industry (2005).

${ }^{(16)}$ The reference to the social patterning of supply and demand does not say anything about the efficiency of the prevailing arrangements. The social patterning of competition, for instance, can lead to the inhibition of the price mechanism. Mark Granovetter and Richard Swedberg have argued that social network ties can lead to the stickiness of prices because economic relations "are embedded in networks that restrain the pure economic forces" (Granovetter and Swedberg 1992: 9). If market actors operate within a network in which competitive pricing is negatively sanctioned, as is the case for exchange relations regulated by guilds, prices will not fluctuate even if this would have positive welfare effects.

$\left({ }^{17}\right)$ For a recently published overview of the current state of economic sociology in France, see Steiner and Vatin (Steiner and Vatin 2009).

$\left.{ }^{18}\right)$ For the investigation of valuation processes in the labor market, see the work by Eymard-Duvernay and Marchal (Eymard-Duvernay and Marchal 1997). Yakubovich, Granovetter, and McGuire (Yakubovich et al. 2005) studied pricing strategies within the American electricity industry in the early twentieth century.

\section{Access brought to you by:}

